\title{
latrogenic Bile Duct Injuries: An Overview and A Review of Literature
}

\author{
Vinoth M. ${ }^{1}$ Abhijit Joshi ${ }^{1}$ \\ ${ }^{1}$ Department of General and Laparoscopic Surgery, Dr. L.H. \\ Hiranandani Hospital, Powai, Mumbai, Maharashtra, India
}

Int J Recent Surg Med Sci 2021;00:37-43.

\author{
Address for correspondence Vinoth M., DNB resident, \\ Dr. L.H. Hiranandani Hospital, Hillside Avenue, Powai, \\ Mumbai 400076, Maharashtra, India \\ (e-mail: vinuvishnu93@gmail.com).
}

\author{
Abstract \\ Keywords \\ - bile duct injury \\ - classification of IBDI \\ - thermal injury \\ - management of bile \\ duct injury
}

\begin{abstract}
Laparoscopic cholecystectomy (LC) is one of the most frequently performed surgical procedures worldwide. latrogenic bile duct injury (IBDI) is a serious complication of LC and has an incidence of 0.3 to $0.7 \%$. Since it is associated with a significant and potentially lifelong morbidity as well as mortality, diagnosing IBDI as early as possible is of paramount importance. Management of bile duct injuries and prognosis of their surgical repair depend on the timing of its recognition, type and the extent of the injury. In this paper, we present a case of IBDI and attempt to discuss all its dimensions.
\end{abstract}

\section{Introduction}

The gold standard for treatment of acute or chronic calculous cholecystitis is laparoscopic cholecystectomy (LC). However, it has a higher incidence $(0.3-0.7 \%)$ of iatrogenic bile duct injuries (IBDIs). ${ }^{1}$ The main principle behind treatment modalities of bile duct injuries is to decompress the biliary tree by improving the transpapillary drainage of bile, thereby minimizing its leakage from the injury site. However, if there is a large injury to or a complete transection of bile duct or biliary obstruction, surgical management becomes the mainstay of treatment.

\section{Case Report}

A 21-year-old man presented with dull, nonradiating upper abdominal pain not relieved with painkillers prescribed by his family doctor. He had undergone LC 6 days back for acute calculous cholecystitis. He did not have any history of fever and vomiting. His pulse rate was $96 / \mathrm{min}$, respiratory rate was $17 / \mathrm{min}$, and body temperature was $36.6^{\circ} \mathrm{C}$, with blood pressure of $110 / 80 \mathrm{~mm} \mathrm{Hg}$. A per abdomen examination revealed guarding over and the abdominal girth was $82 \mathrm{~cm}$. On a contrast-enhanced computed tomography (CECT) scan of the abdomen, large quantity of free fluid was seen in the perihepatic region, paracolic gutters, and the pelvis. An image

DOI https://doi.org/ $10.1055 / \mathrm{s}-0041-1730123$ ISSN $2455-7420$ guided diagnostic tap of the same revealed bile. A telephonic conversation with the initial surgeon (a trained and experienced laparoscopist) who performed the LC revealed that it was a straightforward uneventful procedure with optimum identification of anatomy and no obvious intraoperative bile leak. On admission, his laboratory investigations revealed the following: Hb,15.50 g/dL; total white blood cell count, 19,730; total bilirubin, $1.76 \mathrm{mg} / \mathrm{dL}$; unconjugated bilirubin, $0.99 \mathrm{mg} / \mathrm{dL}$; serum glutamic oxaloacetic transaminase, 24 $\mathrm{U} / \mathrm{L}$; serum glutamic pyruvic transaminase, $31 \mathrm{U} / \mathrm{L}$; alkaline phosphatase, $82 \mathrm{U} / \mathrm{L}$; gamma-glutamic transferase, $63 \mathrm{U} / \mathrm{L}$.

In view of the CECT findings, abdominal signs and onset of early sepsis (pulse rose from 96/min on admission to 118/min by the time imaging was done), a thorough surgical peritoneal toilet and needful was decided upon. At laparoscopy, a large quantity of turbid, infected bile was noted in all the three compartments of the peritoneal cavity. It was sucked out and a thorough peritoneal toilet was given using sterile normal saline ( - Fig. 1). A 2-mm perforation on the anterior surface of common hepatic duct (CHD) with active leak of bile was noted. Cystic duct stump (occluded with two Ligaclips) was identified, but no leakage or blowout was observed from it. The gall bladder fossa on the liver was carefully inspected for bile leak (accessory bile duct injury), but none was observed. The perforation was then suture-closed with simple interrupted stitches using 3-0 Vicryl (-Figs. 2C and 3A, B). Two 32-Fr Romsons

(c)2021. Medical and Surgical Update Society.

This is an open access article published by Thieme under the terms of the Creative Commons Attribution-NonDerivative-NonCommercial-License, permitting copying and reproduction so long as the original work is given appropriate credit. Contents may not be used for commercial purposes, or adapted, remixed, transformed or built upon. (https://creativecommons.org/licenses/by-nc-nd/4.0/).

Thieme Medical and Scientific Publishers Pvt. Ltd. A-12, 2nd Floor, Sector 2, Noida-201301 UP, India 

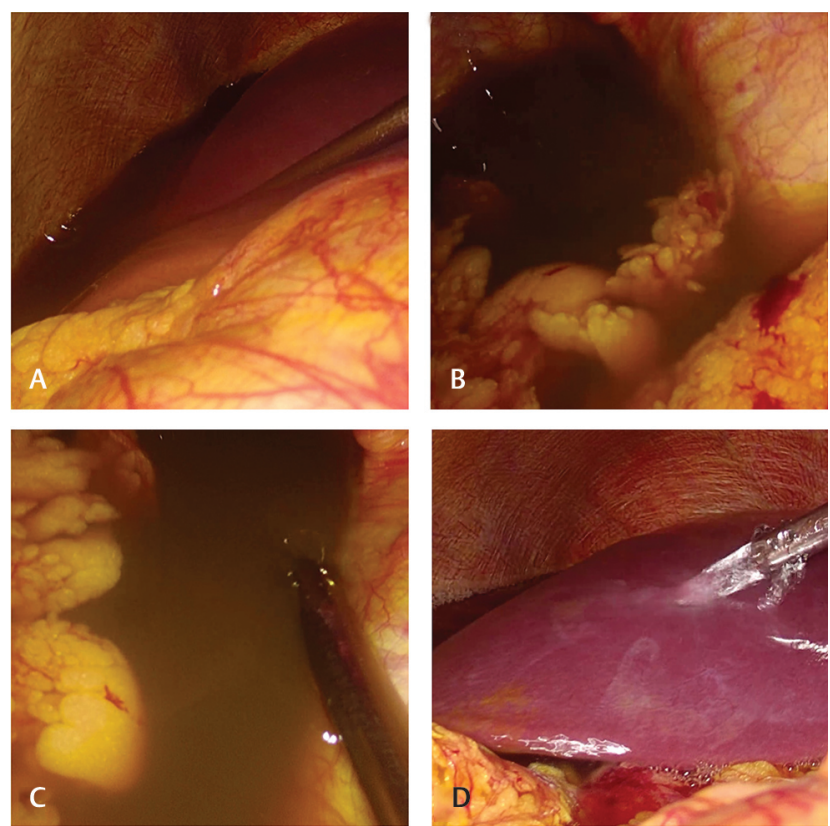

Fig. 1 (A) Turbid bile in right parahepatic space. (B) Turbid bile in pelvis. (C) Leaked bile being suctioned out. (D) Peritoneal toilet being carried out with sterile normal saline.

tube drains were placed in situ, one each in the Morison's pouch and the pelvis ( $\boldsymbol{- F i g}$. 3C, D). The postoperative course of the patient was uneventful and there was no bile leakage. His abdominal signs and laboratory investigations normalized gradually. The drains were removed by postoperative day (POD) 4 and he was discharged on POD 6. On his two outpatient department follow-up visits on POD 10 and POD 30, he was asymptomatic. A telephonic interview was conducted with him at the time of writing this paper; 16 months from his second surgery, and he continues to be symptom-free. Serial blood investigations done in the postoperative period showed progressively normalizing levels ( $\mathbf{- T a b l e} \mathbf{1}$ ).

\section{Discussion}

The fact that our patient was fine in the immediate postoperative period (till POD 4) after the LC indicates that he most probably had a delayed ischemic perforation of the CHD, probably related to the use of monopolar cautery during his LC. The bile duct has a unique axial blood supply at 3 o'clock and 9 o'clock positions. ${ }^{2}$ This peculiar arrangement of the blood supply also contributes to higher incidence of ischemic bile duct injuries when a monopolar cautery is used during the surgery because of the "jumping" phenomenon of the monopolar current. As its current dispersion radius is $2 \mathrm{~cm}$ when applied continuously for more than 3 seconds, excessive dissection along the bile duct margins can result in injury of the axial arteries and lead to ischemic bile duct injuries, which usually present as ischemic strictures, late in the postoperative period. ${ }^{3}$ Animal experiments on thermal effects of monopolar electrosurgery have revealed three mechanisms of injury, namely, the clamp (dispersed injury in the immediate vicinity of the tissue held by the clamp), jumper (injury
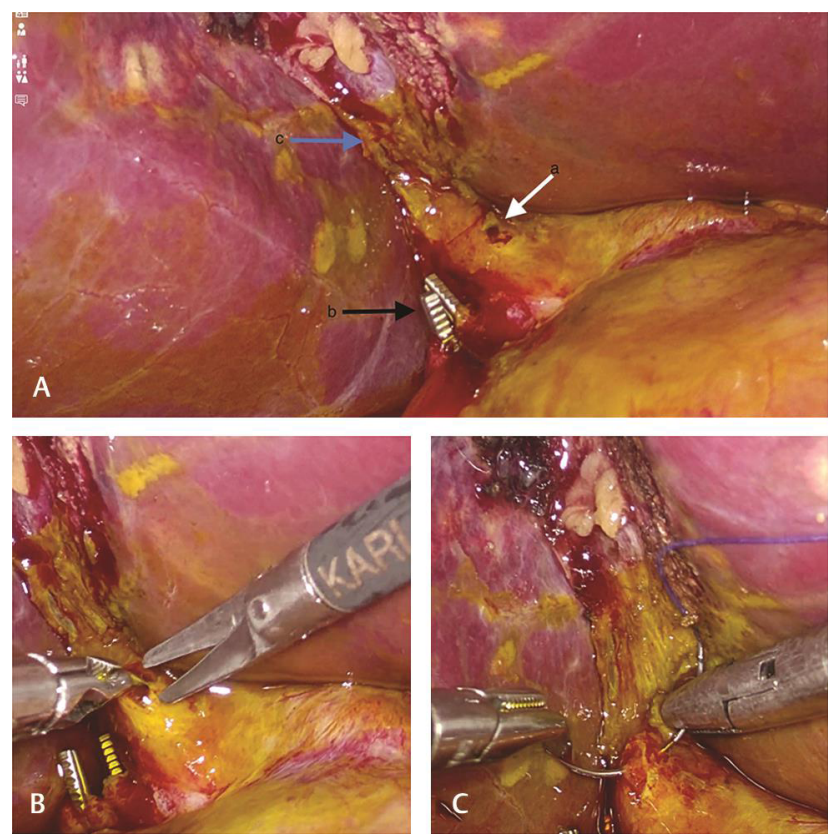

Fig. 2 (A) 2-mm-diameter perforation on anterior surface of CHD (white arrow), intact cystic duct clips with no blow out (black arrow), and no accessory bile duct leakage in the gallbladder fossa (blue arrow). (B) Freshening of edges of the perforation. (C) Suturing of perforation with 3-0 Vicryl.
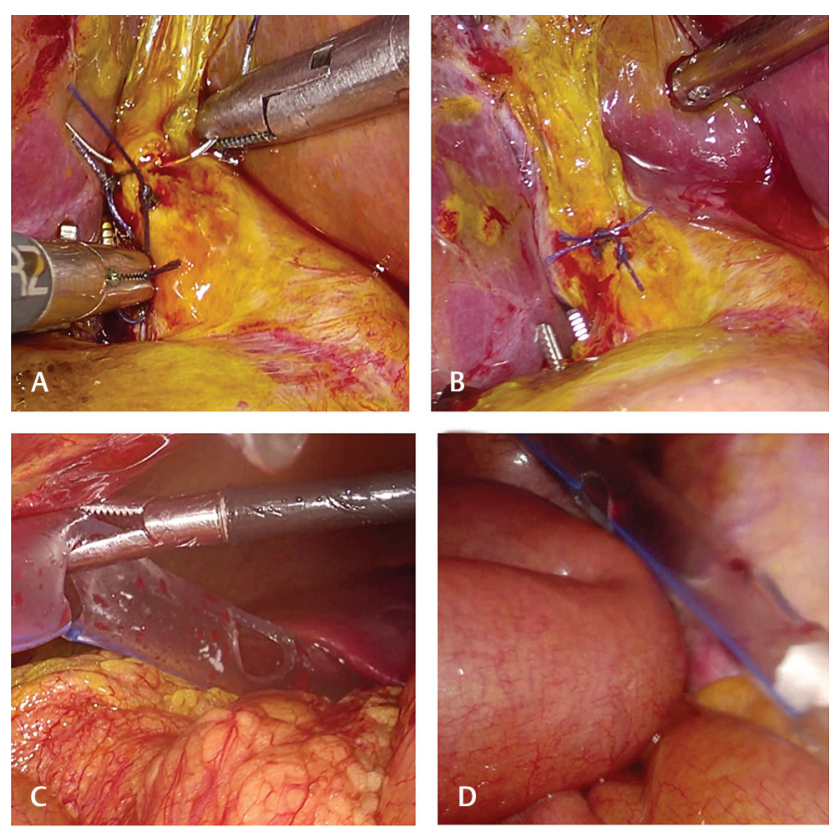

Fig. 3 (A) Third interrupted suture being taken through CHD perforation. (B) Final look of the suture line with no bile leak. 32-Fr Romsons drain being placed in (C) Morison's pouch and (D) pelvis.

to an area nearby, yet not continuous with that held by the clamp), and pedicle (dispersion injury along vascular pedicles) effects. ${ }^{3}$

IBDI can occur due to surgeries performed either in the biliary tract or on other epigastric organs. Out of these two groups, the former has an overall highest incidence of IBDI. ${ }^{4}$ Various classifications have been suggested for IBDI: 
Table 1 Serial laboratory reports of the patient

\begin{tabular}{|c|c|c|c|c|c|c|c|}
\hline & $\begin{array}{l}\text { Prior to } \\
\text { index LC }\end{array}$ & $\begin{array}{l}\text { On } \\
\text { readmission } \\
\text { day (POD } 6 \\
\text { from index } \\
\text { LC) }\end{array}$ & $\begin{array}{l}\text { Pre-op levels } \\
\text { on the day } \\
\text { of bile duct } \\
\text { repair (POD } \\
7 \text { from index } \\
\text { LC) }\end{array}$ & $\begin{array}{l}\text { POD } 1 \\
\text { from } \\
\text { second } \\
\text { surgery }\end{array}$ & $\begin{array}{l}\text { POD } 2 \\
\text { from } \\
\text { second } \\
\text { surgery }\end{array}$ & $\begin{array}{l}\text { POD } 4 \\
\text { from } \\
\text { second } \\
\text { surgery }\end{array}$ & $\begin{array}{l}\text { POD } 8 \\
\text { from second } \\
\text { surgery }\end{array}$ \\
\hline $\mathrm{Hb}(\mathrm{g} / \mathrm{dL})$ & 14.70 & 16.30 & 15.50 & 14.60 & 14.00 & 13.60 & 13.80 \\
\hline Total WBC count & 13,110 & 14,700 & 19,730 & 15,090 & 11,062 & 8,540 & 11,940 \\
\hline $\begin{array}{l}\text { Platelet count } \\
\left(10^{5}\right)\end{array}$ & 2.41 & 2.47 & 2.37 & 2.33 & 2.14 & 2.29 & 3.01 \\
\hline $\begin{array}{l}\text { Total bilirubin } \\
\text { (mg/dL) }\end{array}$ & 0.61 & 0.83 & 1.76 & 1.42 & 1.17 & 1.01 & 0.91 \\
\hline $\begin{array}{l}\text { Unconjugated } \\
\text { bilirubin (mg/dL) }\end{array}$ & 0.24 & 0.66 & 0.99 & 0.86 & 0.78 & 0.68 & 0.57 \\
\hline SGOT (U/L) & 164 & 29 & 24 & 24 & 21 & 26 & 21 \\
\hline SGPT (U/L) & 147 & 48 & 31 & 34 & 36 & 28 & 22 \\
\hline $\begin{array}{l}\text { Alkaline } \\
\text { phosphatase }\end{array}$ & 98 & 93 & 82 & 80 & 72 & 71 & 98 \\
\hline GGT (U/L) & 253 & 74 & 63 & 60 & 60 & 62 & 69 \\
\hline
\end{tabular}

Abbreviations: LC, laparoscopic cholecystectomy; POD, postoperative day; WBC, white blood cell; SGOT, serum glutamic oxaloacetic transaminase; SGPT, serum glutamic-pyruvic transaminase; GGT, gamma-glutamyl transferase .

(1) Bismuth classification: five types of bile duct strictures based on the distance from the hepatic hilum, involvement of the bifurcation of the bile duct, and the right sectoral duct (-Table 2); (2) Strasberg classification: type A to E, added additional biliary injuries such as bile leaks in addition to the Bismuth classification (- Table 2); (3) McMahon classification divided bile duct injuries into major and minor: involvement of less than 25\% circumference of common bile duct (CBD) or cystic duct-CHD junction is considered minor and over $25 \%$ circumference involvement of CBD or postoperative bile duct stricture is considered as major injury; (4) Stewart-Way classification involves the mechanism of IBDI and anatomy of bile duct injury and is divided into class I to

Table 2 Strasberg and Bismuth classifications

\begin{tabular}{|l|l|}
\hline Types & Nomenclature \\
\hline A & $\begin{array}{l}\text { Bile leak from the cystic duct/accessory duct/small } \\
\text { ducts in liver bed without loss of continuity }\end{array}$ \\
\hline B & $\begin{array}{l}\text { Occlusion of an aberrant duct with loss of continuity } \\
\text { with the common bile duct }\end{array}$ \\
\hline C & $\begin{array}{l}\text { Complete transection of the aberrant right hepatic duct } \\
\text { with loss of continuity with common bile duct }\end{array}$ \\
\hline D & Partial lateral wall injury to the CHD or CBD \\
\hline E1 & CHD injury, beyond 2 cm from the primary confluence \\
\hline E2 & CHD injury, less than 2 cm from the primary confluence \\
\hline E3 & Injury at the confluence but confluence is intact \\
\hline E4 & Injury at the confluence but confluence is separated \\
\hline E5 & $\begin{array}{l}\text { Injury to the aberrant right posterior sectoral duct along } \\
\text { with stricture of the CBD }\end{array}$ \\
\hline
\end{tabular}

Abbreviation: CBD, common bile duct; CHD, common hepatic duct. Note: Type I-V of Bismuth classification are same as type E1-E5 with strictures present in biliary tree.
IV (-Table 3); and (5) Amsterdam classification, type A to D. This classification includes four types of ductal injury: type $A$ with leakage from cystic ducts or peripheral hepatic radicles, type $B$ presenting as major bile duct leakage, type $C$ showing an isolated ductal stricture, and type D with complete transection of the bile duct. ${ }^{1}$

The following factors may contribute to an increased risk of IBDI: (1) anatomical anomalies of the biliary tree; (2) coexisting acute or chronic inflammation around the gallbladder; (3) obesity: excess fat within the hepatoduodenal ligament; and (4) poor exposure and bleeding in the surgical area. The most common of all the above-stated factors is the misidentification of biliary anatomy, as it accounts for 70 to $80 \%$ of IBDI. ${ }^{4}$

Patients with IBDI can present with nonspecific symptoms such as pain in the abdomen, fever, nausea, vomiting, and anorexia, along with the following different ways: (1) with

Table 3 Stewart-Way classification

\begin{tabular}{|l|l|}
\hline CLASS I & $\begin{array}{l}\text { CBD is mistaken for cystic duct; but } \\
\text { recognized } \\
\text { E.g., on intraoperative cholangiogram, } \\
\text { incision in cystic duct extends into CBD }\end{array}$ \\
\hline CLASS II & $\begin{array}{l}\text { Bleeding leading to poor visibility, which } \\
\text { results in multiple clips being placed on } \\
\text { CBD/CHD }\end{array}$ \\
\hline CLASS III & $\begin{array}{l}\text { CBD mistaken for cystic duct; not } \\
\text { recognized } \\
\text { E.g., CBD/hepatic ducts transected and/ } \\
\text { or resected }\end{array}$ \\
\hline CLASS IV & $\begin{array}{l}\text { Right hepatic duct (RHD) or right sectoral } \\
\text { duct mistaken for cystic duct } \\
\text { Right hepatic artery (RHA) mistaken for } \\
\text { cystic artery } \\
\text { RHD and RHA transected }\end{array}$ \\
\hline
\end{tabular}

Abbreviation: CBD, common bile duct; CHD, common hepatic duct. 
Table 4 Terblanche clinical classification for assessment of longterm results of surgical bile duct repair

\begin{tabular}{|l|l|l|}
\hline Grade & Result & \\
\hline I & Excellent & $\begin{array}{l}\text { No biliary symptoms with normal liver } \\
\text { function }\end{array}$ \\
\hline II & Good & $\begin{array}{l}\text { Transitory symptoms and normal liver } \\
\text { function }\end{array}$ \\
\hline III & Fair & $\begin{array}{l}\text { Clearly related symptoms requiring medical } \\
\text { therapy and/or deteriorating liver function }\end{array}$ \\
\hline IV & Poor & $\begin{array}{l}\text { Recurrent stricture requiring correction or } \\
\text { related death }\end{array}$ \\
\hline
\end{tabular}

bile leak detected either intraoperatively or postoperatively as seen in the drain (if one was inserted and kept in situ) or as bilioma (if no drain used) with or without signs of sepsis; (2) with stricture in the biliary tree, which can present as jaundice (because of the cholestasis) in the postoperative period. Thus, patients can present with the classic Charcot's triad: pain in the right hypochondrium, fever, and jaundice. However, jaundice is not seen in the first (bile leak) group as there is no cholestasis. ${ }^{4}$

The old, time-tested adage "Prevention is better than cure" applies perfectly to IBDI. Thus, prevention of IBDI is of paramount importance while performing LC. The various proposed methods for prevention are as follows:

- "Critical view of safety" (CVS) technique introduced by Strasberg in 1995. Criteria to achieve CVS include the following:

- The hepatocystic triangle should be cleared of fibrous and adipose tissues.

- CBD and CHD must not be exposed.

- Lower third of gall bladder should be separated from liver bed to expose cystic plate.

- Only two structures, i.e., cystic duct and the cystic artery, should be seen entering the gall bladder. ${ }^{5}$

- Infundibular method, in which the surgeon works very close to infundibulum of the gall bladder to avoid biliary injuries. However, in hidden cystic duct syndrome, the cystic duct, which is hidden, can give a false perception of infundibulum. As a result of it, CBD can be misinterpreted as cystic duct and can lead to bile duct injuries. ${ }^{6}$

- Antegrade dissection or "fundus-first" technique can be used to prevent IBDI.

- Subtotal or partial cholecystectomy, in which the posterior wall of the gall bladder is left attached to the liver and the cystic duct is secured at its origin itself. ${ }^{7}$

- B-SAFE method helps the surgeons to have a correct intraoperative cognition map. B, bile duct; $\mathrm{S}$, sulcus of Rouvière; A, hepatic artery; F, umbilical fissure; $\mathrm{E}$, enteric (duodenum).

- Routine or selective use of intraoperative cholangiography is still under debate. ${ }^{8}$

- Laparoscopic ultrasound can also be used.

- Near-infrared fluorescent cholangiography is the latest innovation which shows better results. It also delineates the structures in Calot's triangle very clearly and helps in avoiding the biliary injuries. ${ }^{9}$
- Identification of different anatomical landmarks, such as Rouvière's sulcus, 2 to $5 \mathrm{~cm}$ in length and runs right of the liver hilum, can be used as a starting point while starting the dissection or the identification of Mascagni's node, which should be the medial end of the dissection, can be very helpful in avoiding IBDI. ${ }^{10,11}$

The Society of American Gastrointestinal Endoscopic Surgeons (SAGES) has launched a new initiative in order to improve safety in LC, headed by the Safe Cholecystectomy Task Force (SCTF). It seeks to encourage a culture of safety in LC and to reduce biliary injury. To elucidate the crucial issues, an expert consensus study was conducted to identify factors considered most important to reach this goal. The following top five most important factors linked to safe practice were denominated: (1) establishing CVS, (2) understanding of relevant anatomy, (3) appropriate retraction/exposure, (4) knowing when to call for help, and (5) recognizing the need for conversion or an alternate procedure (such as subtotal cholecystectomy). ${ }^{12}$

Laboratory and radiological investigations can be used concurrently for the diagnosis of IBDI. In patients with minimal bile leakage with no other complications, the levels of aminotransferases may be normal with increased levels of cholestasis markers, as the biliary cirrhosis has not set in. Ultrasound of the abdomen can be the initial investigation that helps in identification of free fluid in the right hypochondrium. CT scan of the abdomen can be aimed at finding the fluid collections, biliary obstructions, and any associated vascular lesions such as that of right hepatic artery. However, the gold standard nowadays is magnetic resonance cholangiopancreatography (MRCP), as this helps in the proper delineation of the biliary anatomy. If done using a contrast, MRCP can also be helpful in identifying the biliary leaks as the contrast tends to extravasate from the injury site.

Management of the bile duct injuries can be done by either endoscopic, radiological, or surgical interventions ( - Fig. 4). The endoscopic management is recommended for initial treatment of benign biliary stricture or in biliary fistula or when surgery is not feasible. Endoscopic dilatation with insertion of biliary prosthesis during endoscopic retrograde cholangiopancreatography (ERCP) is the most commonly performed endoscopic procedure in the treatment of IBDI. Minimally invasive radiological interventions such as percutaneous transhepatic biliary drainage can also complement the treatment plan if the injury is detected more than 72 hours after the initial surgery. A dilated proximal ductal system helps this, but in collapsed systems, it can be challenging.

Surgical treatment of IBDI can vary based on the timing of the recognition of the injury and extent of the injury. The ultimate goal is to restore the normal bile flow into the intestine by reconstruction of the injured biliary tree.

- If diagnosed intraoperatively: Depending on the expertise, it can be managed laparoscopically or by open surgery. If the diameter of the injured duct is less than $3 \mathrm{~mm}$, then it can be ligated to prevent any bile leak postoperatively. If it is more than $3 \mathrm{~mm}$, it should be repaired as it drains a significant part of liver. ${ }^{13}$ In case of complete transection 


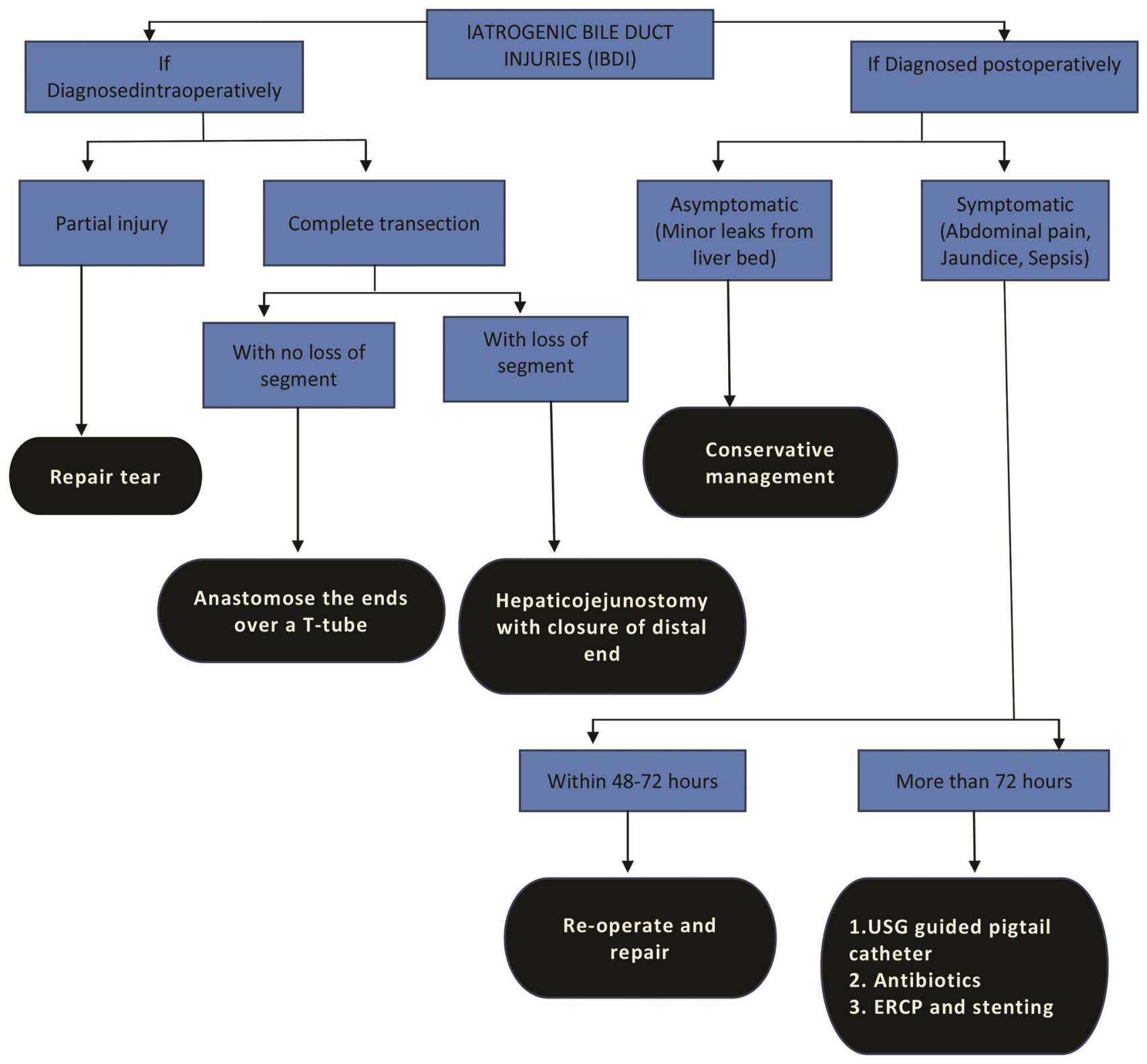

Fig. 4 Flow chart of diagnosis and management of IBDI.

of $\mathrm{CHD}$ or $\mathrm{CBD}$, if there is no loss of segment, tension-free end-to-end anastomosis with or without T-tube can be done. However, if there is a loss of segment or tension-free anastomosis is not possible, RouX-en-Y hepaticojejunostomy is the only option. ${ }^{4}$

- If diagnosed postoperatively: This phase can be divided into two groups of early postoperative (within 48-72 hours) and late postoperative (more than 72 hours) diagnosis. Patients can be taken up for immediate reoperation and repair in the former group, whereas initial supportive and other means of management such as ultrasound-guided pigtail catheter insertion and ERCP with stenting are helpful in the latter. The aim of the above-mentioned conservative approaches in the second group is to buy some time as the tissues are friable in this group. There can be presence of local or generalized sepsis, which makes the definitive repair of the bile duct a cumbersome process with high chances of postoperative complications. The definitive repair of the injuries can be planned approximately after 6 weeks, depending on the general health condition of the patient. ${ }^{14}$

The definitive surgical procedure for IBDI can be either a surgical repair or a reconstructive procedure. Roux-en-Y hepaticojejunostomy is preferred by most surgeons in cases of extensive bile duct injury because it has lesser complication of stricture formation postoperatively as compared to end-to-end anastomosis of the bile duct. The latter has higher chances of suture cut-through, if there is increased tension between both the ends, and also formation of strictures, which results in increased morbidity in the postoperative course. However, this shortcoming of the end-to-end anastomosis can be overcome by extensive mobilization of the duodenum and the pancreatic head to create adequate 
Table 5 Review of the literature on IBDI

\begin{tabular}{|c|c|c|c|c|}
\hline Authors & $\begin{array}{l}\text { Journal } \\
\text { (year of } \\
\text { publication) }\end{array}$ & $\begin{array}{l}\text { Type of } \\
\text { study }\end{array}$ & $\begin{array}{l}\text { No. of } \\
\text { patients }\end{array}$ & Methods/Observations \\
\hline $\begin{array}{l}\text { Jabłońska and } \\
\text { Lampe }^{4}\end{array}$ & $\begin{array}{l}\text { World Journal of } \\
\text { Gastroenterology } \\
\text { (2009) }\end{array}$ & Review article & NA & $\begin{array}{l}\text { - Early recognition and appropriate treatment are needed for IBDI } \\
\text { - Following repair, long-term postoperative follow-up is required }\end{array}$ \\
\hline Renz et al ${ }^{15}$ & $\begin{array}{l}\text { Visceral medicine } \\
(2017)\end{array}$ & Review article & NA & $\begin{array}{l}\text { - In general, endoscopic techniques are recommended for the initial diag- } \\
\text { nosis and treatment of IBDI and are important to classify them correctly } \\
\text { - In patients with complete dissection or obstruction of the bile duct, surgi- } \\
\text { cal management remains the only feasible option }\end{array}$ \\
\hline Jabłońska ${ }^{17}$ & $\begin{array}{l}\text { World Journal of } \\
\text { Gastroenterology } \\
\text { (2013) }\end{array}$ & Review article & NA & $\begin{array}{l}\text { - Hepatectomy is not a standard procedure in surgical treatment of IBDI, } \\
\text { but in some complex injuries it should be considered } \\
\text { - Cases requiring hepatectomy are divided into early (injury-related necro- } \\
\text { sis) and late (atrophy caused by long-term recurrent cholangitis }\end{array}$ \\
\hline Jabłońska et al ${ }^{18}$ & \begin{tabular}{|l|} 
Journal of \\
Gastrointestinal \\
surgery (2009)
\end{tabular} & $\begin{array}{l}\text { Comparative } \\
\text { study }\end{array}$ & 94 & $\begin{array}{l}\text { - More early complications occurred after HJ than after EE } \\
\text { - Long-term results were comparable after both reconstructive methods } \\
\text { - After EE, patients achieved a higher weight gain than after HJ } \\
\text { - Quality of life in both groups was comparable }\end{array}$ \\
\hline $\begin{array}{l}\text { Gallagher and } \\
\text { Imagawa }\end{array}$ & $\begin{array}{l}\text { Journal of } \\
\text { Surgical Case } \\
\text { Reports (2019) }\end{array}$ & Case report & 01 & $\begin{array}{l}\text { - External biliary catheter caused the fistula formation } \\
\text { - Consideration should be given to delay reconstruction of a biliary injury } \\
\text { with a concomitant right hepatic artery injury to allow for collateralization } \\
\text { - Biliary-enteric fistulas after bile duct injuries should be obliterated during } \\
\text { elective biliary reconstruction surgery to avoid fistula stricture and its } \\
\text { complications }\end{array}$ \\
\hline $\begin{array}{l}\text { Rifatbegovic } \\
\text { et al }{ }^{20}\end{array}$ & $\begin{array}{l}\text { International } \\
\text { Journal of } \\
\text { Surgery Case } \\
\text { Reports (2018) }\end{array}$ & Case report & 01 & $\begin{array}{l}\text { - Roux-en-Y hepaticojejunostomy without transhepatic biliary stent and } \\
\text { also without Witzel drainage can be successfully used for surgical repair } \\
\text { of IBDI }\end{array}$ \\
\hline Mercado et $\mathrm{a}^{21}$ & $\begin{array}{l}\text { Surgical } \\
\text { Endoscopy } \\
(2003)\end{array}$ & $\begin{array}{l}\text { Retrospective } \\
\text { study }\end{array}$ & 204 & $\begin{array}{l}\text { - Two groups, anastomosis at confluence and below confluence: long-term } \\
\text { evaluation done } \\
\text { - In the acute setting, complex lesions should be treated with a high bil- } \\
\text { ioenteric anastomosis (at the junction level) in the first attempt at repair } \\
\text { - Lower-level anastomoses are associated with a higher dysfunction rate } \\
\text { and the need for radiological manipulation and reoperation } \\
\text { - Stenosis of the anastomosis secondary to undetected duct ischemia in the } \\
\text { acute repair is more frequent in low bilioenteric anastomoses }\end{array}$ \\
\hline Nechay et al ${ }^{3}$ & $\begin{array}{l}\text { BMC Surgery } \\
(2020)\end{array}$ & $\begin{array}{l}\text { Research } \\
\text { article }\end{array}$ & 8 rabbits & $\begin{array}{l}\text { - Appendectomy with monopolar cautery at } 30 \text { and } 60 \mathrm{~W} \text { performed, dam- } \\
\text { age assessed by high-resolution infrared camera and on autopsy } \\
\text { - The key factor leading to cautery injury due to lateral thermal spread is } \\
\text { duration of application and not the power setting } \\
\text { - The spread-generated heat through tubular anatomic structures can } \\
\text { cause thermal injury to the intestinal wall in the regions distant to the } \\
\text { surgical site, its necrosis, and even perforation }\end{array}$ \\
\hline
\end{tabular}

Abbreviations: EE, end to end anastomosis; $\mathrm{HJ}$, hepatico-docho-jejunostomy; IBDI, iatrogenic bile duct injury.

length and a tension-free anastomosis. ${ }^{4}$ The normal physiology of the biliary drainage is maintained in the end-to-end anastomosis. In Roux-en-Y hepaticojejunostomy, the duodenum and the proximal part of the jejunum are bypassed and can result in side effects such as hypersecretion of gastric contents. As a result, a higher number of duodenal ulcers has been noted in patients who have undergone Roux-en-Y hepaticojejunostomy because of the loss of the neutralizing effect of bile over the gastric secretion. ${ }^{16}$

The major postoperative problem of the bile duct repair is the development of strictures, thus leading to an impairment in the quality of life. Thus, the success of the repair depends on the nondevelopment of the strictures. In specialized hepatobiliary centers, the success rate is 70 to $90 \%$. About two-thirds of the strictures develop within 2 to
3 years of reconstruction, $80 \%$ within 5 years, and $90 \%$ within 7 years. ${ }^{4}$ Terblanche clinical grading, using the clinical biliary symptomatology, helps in the long-term assessment of the surgical repair of the bile duct ( - Table 4 ).

A comprehensive review of the literature covering all the dimensions of IBDI is summarized in - Table 5.

\section{Conclusion}

Prevention is better than cure in IBDI, as, even after optimally timed appropriate therapy at the hands of an experienced operator, there are significant risks of recurrent complications. Those presenting within the first 72 hours do well with definitive surgical repair. Those who present more than 72 hours after the initial surgery should be managed 
with drainage of collections by image-guided pigtail catheter insertion and interventional radiological or endoscopic means. This gives time for the local and general sepsis to settle down. A definitive surgical repair can then be planned and performed 6 weeks later. Our patient did well with primary repair because he was young, the injury was small, and the intervention was timely.

\section{Conflict of Interest}

None declared.

\section{References}

1 Pesce A, Palmucci S, La Greca G, Puleo S. Iatrogenic bile duct injury: impact and management challenges. Clin Exp Gastroenterol 2019;12:121-128

2 Jabłońska B. The arterial blood supply of the extrahepatic biliary tract - surgical aspects. Pol J Surg 2008;80(6):336-342

3 Nechay TV, Titkova SM, Anurov MV, et al. Thermal effects of monopolar electrosurgery detected by real-time infrared thermography: an experimental appendectomy study. BMC Surg 2020;20(1):116

4 Jabłońska B, Lampe P. Iatrogenic bile duct injuries: etiology, diagnosis and management. World J Gastroenterol 2009;15(33):4097-4104

5 Strasberg SM, Brunt LM. Rationale and use of the critical view of safety in laparoscopic cholecystectomy. J Am Coll Surg 2010;211(1):132-138

6 Daly SC, Deziel DJ, Li X, et al. Current practices in biliary surgery: do we practice what we teach? Surg Endosc 2016;30(8):3345-3350

7 Bornman PC, Terblanche J. Subtotal cholecystectomy: for the difficult gallbladder in portal hypertension and cholecystitis. Surgery 1985;98(1):1-6

8 Sutherland F, Dixon E. The importance of cognitive map placement in bile duct injuries. Can J Surg 2017;60(6):424-425

9 Pesce A, Latteri S, Barchitta M, et al. Near-infrared fluorescent cholangiography - real-time visualization of the biliary tree during elective laparoscopic cholecystectomy. HPB (Oxford) 2018;20(6):538-545
10 Hugh TB, Kelly MD, Mekisic A. Rouvière's sulcus: a useful landmark in laparoscopic cholecystectomy. $\mathrm{Br}$ J Surg 1997;84(9):1253-1254

11 Ferzli G, Timoney M, Nazir S, Swedler D, Fingerhut A. Importance of the node of Calot in gallbladder neck dissection: an important landmark in the standardized approach to the laparoscopic cholecystectomy. J Laparoendosc Adv Surg Tech A 2015;25(1):28-32

12 Pucher PH, Brunt LM, Davies N, et al; SAGES Safe Cholecystectomy Task Force. Outcome trends and safety measures after 30 years of laparoscopic cholecystectomy: a systematic review and pooled data analysis. Surg Endosc 2018;32(5):2175-2183

13 Seeras K, Qasawa RN, Kashyap S, Kalani AD, Bile Duct Repair. In: StatPearls [Internet]. Treasure Island, FL: StatPearls Publishing; 2020

14 Walsh RM, Henderson JM, Vogt DP, Brown N. Long-term outcome of biliary reconstruction for bile duct injuries from laparoscopic cholecystectomies. Surgery 2007;142(4):450-456, discussion 456-457

15 Renz BW, Bösch F, Angele MK. Bile duct injury after cholecystectomy: surgical therapy. Visc Med 2017;33:184-190

16 Nielsen ML, Jensen SL, Malmstrøm J, Nielsen OV. Gastrin and gastric acid secretion in hepaticojejunostomy Roux-en-Y. Surg Gynecol Obstet 1980;150(1):61-64

17 Jabłońska B. Hepatectomy for bile duct injuries: when is it necessary? World J Gastroenterol 2013;19(38):6348-6352

18 Jabłońska B, Lampe P, Olakowski M, Górka Z, Lekstan A, Gruszka T. Hepaticojejunostomy vs. end-to-end biliary reconstructions in the treatment of iatrogenic bile duct injuries. J Gastrointest Surg 2009;13(6):1084-1093

19 Gallagher SP, Imagawa DK. Spontaneous choledochoduodenal fistula in a patient with a bile duct injury following laparoscopic cholecystectomy. J Surg Case Rep 2019;2019(5):rjz141

20 Rifatbegovic Z, Kovacevic M, Nikic B. Treatment of late identified iatrogenic injuries of the right and left hepatic duct after laparoscopic cholecystectomy without transhepatic stent and Witzel drainage: Case report. Int J Surg Case Rep 2018;48:72-75

21 Mercado MA, Chan C, Orozco H, Tielve M, Hinojosa CA. Acute bile duct injury. The need for a high repair. Surg Endosc 2003;17(9):1351-1355 